Reprod. Nutr. Dévelop., 1987, 27 (3), 659-672.

\title{
Relationship between in vitro digestion of proteins and in vivo assessment of their nutritional quality ( $\left.{ }^{1}\right)$
}

\author{
C. VACHON, Sylvie GAUTHIER, Ruth CHARBONNEAU, L. SAVOIE $\left(^{2}\right)$
}

with the assistance of G. PARENT for amino acid analysis and P. PROVENCHER for the statistical analysis

\author{
Département de Nutrition humaine et de Consommation, \\ Faculté des Sciences de l'Agriculture et de l'Alimentation \\ Centre de Recherche en Nutrition, Université Laval, Québec, Canada, G1K 7P4
}

Summary. The relationship between the nature of in vitro digestion products and protein quality evaluation in rats was established. Eleven protein sources of animal and vegetable origin and of various purities were digested by pepsin then by pancreatin in a dialysis bag of 1000 molecular weight cutoff. Animal proteins were generally better digested in vitro than vegetable proteins. Amino acid release partly reflected enzyme specificity and varied depending on the nature of the protein. Essential amino acids were generally released rapidly at the expense of non-essential amino acids. The composition of protein hydrolysis products was thus markedly different from that of the protein before digestion. Digestibility determination in rats showed much less variation between proteins than the in vitro method; the two digestibility measurements did not correlate. However, by using stepwise multiple regression analysis, the amino acid composition of in vitro digestion products was found to correlate with the protein efficiency ratio (PER) more accurately than protein composition $\left(R^{2}=0.981\right.$ and 0.934 , respectively). A regression analysis with net protein ratio (NPR) gave lower $R^{2}$ coefficients than with PER (0.941 and 0.921 , respectively). When regression equations were employed to predict the PER and digestion products were used instead of protein composition, an improvement was seen for almost all the test proteins, especially beef, rapeseed and wheat gluten. Better evaluation of protein quality by the use of protein digestion products demonstrates the possible impact of amino acid availability on protein quality.

\section{Introduction.}

The nutritional quality of a protein is primarily related to its amino acid composition. However, amino acid availability is also a key factor of protein quality. Availability depends on the process of digestion, which may be affected by many factors such as the characteristics of the protein itself (Silano, 1976 ; Stahmann

(1) Contribution No 13 from « Centre de Recherche alimentaire de Saint-Hyacinthe, Direction de la Recherche, Agriculture Canada, Saint-Hyacinthe, Québec, Canada, J2S $4 Z 4$.

(2) Send reprint request to Laurent Savoie, Centre de Recherche en Nutrition. Pavillon PaulComtois, Université Laval, Québec, Canada, G1K 7P4. 
and Woldegiorgis, 1975), the presence of anti-nutritional factors (Green and Nasset, 1983 ; Liu, Means and Feeney, 1971), or interactions with other components of the foodstuff such as carbohydrates (Forsum, 1975; Bloomgarden et al., 1981). One or more of these factors can be positively or negatively influenced by food processing.

Assays combining enzymatic hydrolysis with amino acid analysis attempt to evaluate the availability of individual amino acids since they provide data on how much of each is released from the protein. Different systems consisting of one or several enzymes in one or more steps were developed (Stahmann and Woldegiorgis, 1975 ; Sheffner, Eckfeldt and Spector, 1956 ; Buchanan, 1969). The major limitations of these methods are the lack of a suitable way of separating the digestion products from the digesta and, eventually, their incapacity to reproduce in vivo digestion.

Gauthier et al. (1982) developed an in vitro digestion method based on the original approach of Mauron et al. (1955) which considerably reduced the abovementioned drawbacks. It consisted of pepsin digestion of the protein followed by enzymatic hydrolysis with pancreatin. The latter step was carried out in a highly selective dialysis bag with a 1000 molecular weight cutoff for the simultaneous selection and removal of digestion products by a circulating dialysis buffer. The design and flow parameters of the digestion apparatus were modified and a " digestion cell " with a high analytical capacity and better accuracy and reproducibility was developed (Savoie and Gauthier, 1986). The enzymatic parameters of the method were reevaluated and adjusted (Gauthier, Vachon and Savoie, 1986).

The purpose of the present work was to examine the degree of correspondance of this method with the in vivo situation. Eleven different protein sources were digested in the digestion cell and the data were correlated with the in vivo nutritional evaluation of proteins in rats : protein efficiency ratio (PER), net protein ratio (NPR) and apparent digestibility.

\section{Material and methods.}

Animals and diets. - PER and NPR were measured according to Pellett and Young (1980) using male Sprague-Dawley rats (Canadian Breeding Farm, StConstant, Québec). The rats were housed individually in mesh-bottomed cages under controlled conditions $\left(24^{\circ} \mathrm{C}, 50 \%\right.$ humidity, lights-on between 07 and $19 \mathrm{~h}$ ). Upon arrival, they were fed a non-purified diet (Purina Rat Chow, Ralston Purina, St-Louis, M0) with water ad libitum for 3 days. After that, the rats (mean body weight : $70.5 \pm 0.5 \mathrm{~g}$ ) were divided into twelve groups of ten each and fed ad libitum purified diets containing $10 \%$ crude protein (table 1 ) for 28 days. A protein-free diet containing $854 \mathrm{~g}$ of corn starch, $50 \mathrm{~g}$ of cellulose and all the basal ingredients was given to group 12 for 10 days and used to measure the NPR. Food was replaced every other day. Food consumption for the period was recorded after correction for spillage. Stools were collected from day 6 to day 10 
included and apparent digestibility was calculated relative to $\mathrm{Cr}_{2} \mathrm{O}_{3}$ (Christian and Coup, 1954) as a non-absorbable marker using the following equation :

digestibility $(\%)=100-100\left(\frac{\mathrm{Cr} \text { diet }}{\mathrm{N}} \div \frac{\mathrm{Cr} \text { stools }}{\mathrm{N}}\right)$.

Nitrogen was determined by an automated Kjeldahl method (Model 16210 KjellFoss Autoanalzer, Foss Co., Denmark).

TABLE 1

Crude protein content of protein sources and diet composition on a $\mathrm{kg}$ basis (").

\begin{tabular}{|c|c|c|c|c|}
\hline \multirow[b]{2}{*}{ Protein sources } & \multirow[b]{2}{*}{$\begin{array}{l}\% \text { Protein } \\
(\mathrm{N} \times 6.25)\end{array}$} & \multicolumn{3}{|c|}{ Quantity used in the diets (g) } \\
\hline & & Protein & Corn starch & Cellulose $\left({ }^{2}\right)$ \\
\hline Egg $(3,4) \ldots \ldots$ & 70.2 & 142.5 & 626.3 & 86.2 \\
\hline Lactalbumin $(5)$ & 84.8 & 117.9 & 655.6 & 81.5 \\
\hline Beef $(3,4) \ldots \ldots$ & 85.6 & 116.8 & 674.6 & 63.6 \\
\hline Rapeseed $(6)$. & 67.0 & 149.3 & 651.0 & 54.8 \\
\hline Casein ICN (5) ... & 87.8 & 113.9 & 686.1 & 55.1 \\
\hline Casein ANRC $(7)$ & 92.5 & 108.1 & 691.4 & 55.5 \\
\hline Soybean (5) .... & 67.5 & 148.1 & 652.1 & 54.7 \\
\hline Oatmeal (4) .... & 17.4 & 574.7 & 151.5 & 128.3 \\
\hline Peanut meal (5) & 47.3 & 211.4 & 581.5 & 62.1 \\
\hline Wheat flour $(4)$. & 16.0 & 625.0 & 187.5 & 42.5 \\
\hline Wheat gluten $\langle 5\rangle^{\circ}$ & 82.5 & 121.5 & 654.2 & 79.6 \\
\hline
\end{tabular}

(1) Other ingredients per $\mathrm{kg}$ diet were : a) $100 \mathrm{~g}$ of corn oil ; b) $1 \mathrm{~g} \mathrm{Cr}_{2} \mathrm{O}_{3}$; c) $35 \mathrm{~g}$ of Mineral Mix (AIN-76, ICN Nutritional Biochemicals, Cleveland, OH) (13) ; d) $10 \mathrm{~g}$ of vitamin mixture (Vitamin Fortification Mixture, Teklad, Madison, Wl), supplying in $\mathrm{mg} / \mathrm{kg}$ diet : retinyl palmitate, $39.7(19,850 \mu)$, ergocalciferol, $4.4(2200 \mu), \alpha$-tocopheryl acetate, $485(121 \mu)$, ascorbic acid, 987, 1-inositol, 110.2, choline dihydrogen citrate, 3715 , menadione, 49.6, p-aminobenzoic acid, 110.2, niacin, 99.2, riboflavin, 22, pyridoxine $\mathrm{HCl}, 22$, thiamin $\mathrm{HCl}, 22$, calcium pantothenate, 66.1 , biotin, 0.44 , folic acid, 1.98 , vitamin $\mathrm{B}_{12}, 29.8$.

(2) Alphacel (non nutritive bulk, ICN).

(3) Ether extract of the freeze-dried product.

(4) Purchased from a local dealer. Beef was sirloin steak.

(5) ICN Nutritional Biochemicals, Cleveland, $\mathrm{OH}$.

(6) Low glucosinolate rapeseed protein prepared by FRI-75, a process from the food Research Institute, Agriculture Canada, Ottawa (a generous gift).

(7) Animal Nutrition Research Council, ANRC (Sheffields Products, Memphis, TE).

Diet composition is given in table 1. The protein sources were of different purity : the two caseins, lactalbumine and wheat gluten were obtained as purified protein sources, while the others were partially purified either in the laboratory (egg and beef) or by the dealer (rapeseed, soybean, oatmeal, peanut meal and wheat flour). In order to keep a constant protein : energy ratio among the diets, the energy content of the diet components was measured by bomb calorimetry (Parr Adiabatic Calorimeter, Moline, IL); corn starch served to adjust gross energy at $4.06 \mathrm{Kcal} / \mathrm{g}$ and cellulose was used as a filler. For example, it was necessary to reduce corn starch in the oatmeal diet and to add non-nutritive cellulose as a filler because the energy density of this protein source was high and much was needed in the diet to obtain a $10 \%$ protein level. 
In vitro digestion with dialysis. - The protein sources were digested according to the method of Gauthier, Vachon and Savoie (1986), i.e. 30 min digestion of $250 \mathrm{mg}$ of protein $(\mathrm{N} \times 6.25)$ with $1 \mathrm{mg}$ of pepsin (1:600, Sigma, St-Louis, M0) at $37^{\circ} \mathrm{C}$ in $0.1 \mathrm{~N} \mathrm{HCl}$ adjusted to $\mathrm{pH} 1.9$ with $\mathrm{N} \mathrm{NaOH}$; the mixture was then digested at $\mathrm{pH} 7.5$ with $10 \mathrm{mg}$ of pancreatin $(5 \mathrm{X}, \mathrm{ICN})$ at $37{ }^{\circ} \mathrm{C}$ in a " digestion cell " (Savoie and Gauthier, 1986) as follows : the reaction was carried out in a dialysis bag of 1000 molecular weight cutoff for the simultaneous selection and removal of the digestion products in a $10 \mathrm{mM}$ sodium phosphate buffer, $\mathrm{pH} 7.5$. The buffer was pumped through the digestion cell at a rate of $1.6 \mathrm{ml} / \mathrm{min}$ by a peristaltic pump. Samples of the dialysate (digested material) were collected every hour for $6 \mathrm{~h}$ and stored at $-20^{\circ} \mathrm{C}$ for nitrogen determination by an autonalayzer (method No. 329-74 W/B from Technicon Instruments, Tarrytown, N.Y.) and for amino acid analysis. To obtain the protein and amino acid digestibilities of table 3 , the pool of the six time samples was analysed. Pancreatin was a crude preparation containing all the pancreatic erizymes; trypsin and chymotrypsin activities were measured giving 2.2 TAME units and 4.1 ATEE units, respectively, per mg of protein (Gauthier, Vachon and Savoie, 1986).

Crude protein and amino acid digestibilities (\%) after $6 \mathrm{~h}$ of digestion with pancreatin were calculated from the following equations :

$\begin{gathered}\text { Crude protein } \\ \text { digestibility }\end{gathered} \frac{\text { quantity of } N \text { recovered in the dialysate }}{\text { quantity of } N \text { used in the assay }} \times 100$

$\begin{array}{cc}\text { Amino acid } & \begin{array}{c}\text { quantity of a given amino acid } \\ \text { recovered in the dialysate }\end{array} \\ \text { digestibility } & \begin{array}{c}\text { content of the amino acid in } \\ \text { the test protein sample }\end{array}\end{array}$

Amino acid analysis. - Acid hydrolysis of either the protein sources or the dialysate was performed according to Simpson et al. (1976). Two mg of the protein were suspended in vacuum tubes in $1 \mathrm{ml}$ of $4 \mathrm{~N}$ methanesulfonic acid with $0.2 \%$ 3-(2 aminoethyl) indole added (Vacuum reaction tubes, Pierce, Rockford, IL). Gaseous nitrogen was flowed into the tubes for $2 \mathrm{~min}$ to remove the air and the tubes were frozen in a mixture of liquid nitrogen and acetone. After a vacuum was created, the tubes were allowed to thaw slowly. This procedure was repeated once. Hydrolysis was carried out at $110^{\circ} \mathrm{C}$ for $24 \mathrm{~h}$; the hydrolysate was then partially neutralized with $1 \mathrm{ml}$ of $3.5 \mathrm{~N} \mathrm{NaOH}$ and filtered successively through Whatman No. 1 and $0.22 \mu \mathrm{m}$ Millipore filters. The internal standard $(0.2 \mu \mathrm{mole}$ norleucine) was added before hydrolysis. Amino acid analysis was performed by ion-exchange chromatography (Model 4000 autoanalyzer, LKB Instruments, Rockwell, MD). The tryptophan content of oatmeal, peanut meal and wheat flour were not recorded because appreciable losses occur with methane-sulfonic acid hydrolysis when the protein samples contain more than $20 \%$ carbohydrates (Simpson et al., 1976).

Statistical analysis. - In vivo data and crude protein in vitro digestibility were submitted to an analysis of variance and evaluated with Duncan's multiple-range test (Duncan, 1955). The relationship between in vitro and in vivo data was esta- 
blished by Pearson's correlation test and stepwise multiple regression analysis using a computerized system (SAS Institute, 1979).

\section{Results.}

Amino acid content of test proteins. - The great diffence between the test proteins was their protein content (table 1) and amino acid profile (table 2). Sources of animal origin contained more protein than those of vegetable origin, with the exception of wheat gluten. Also, the essential amino acid content of the former proteins was higher. Methionine and cysteine contents were lower than reported values (Sarwar et al., 1983). On the other hand, the fact that amino acids of both the protein sources and their digestion products were analysed using the same method minimized the possibility of bias in comparing the capacity of both amino acid profiles to predict protein quality.

TABLE 2

Amino acid composition of test proteins $(\mathrm{g} / 100 \mathrm{~g}$ amino acids).

\begin{tabular}{|c|c|c|c|c|c|c|c|c|c|c|c|c|}
\hline & & Egg & $\begin{array}{l}\text { Lactal- } \\
\text { bumin }\end{array}$ & Beef & $\begin{array}{l}\text { Rape- } \\
\text { seed }\end{array}$ & $\begin{array}{c}\text { Casein } \\
\text { ICN }\end{array}$ & $\begin{array}{l}\text { Casein } \\
\text { ANRC }\end{array}$ & $\begin{array}{l}\text { Soy- } \\
\text { bean }\end{array}$ & $\begin{array}{l}\text { Oat- } \\
\text { meal }\end{array}$ & $\begin{array}{c}\text { Peanut } \\
\text { meal }\end{array}$ & $\begin{array}{l}\text { Wheat } \\
\text { flour }\end{array}$ & $\begin{array}{l}\text { Wheat } \\
\text { gluten }\end{array}$ \\
\hline CYS & & $1.63^{1}$ & 1.66 & 0.57 & 1.06 & 0.88 & 0.76 & 0.73 & 1.82 & 0.77 & 1.14 & 1.40 \\
\hline ASP & 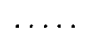 & 10.36 & 10.63 & 10.07 & 8.17 & 7.61 & 7.39 & 11.80 & 9.92 & 12.15 & 4.82 & 3.94 \\
\hline THR & 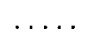 & 4.91 & 5.18 & 4.67 & 4.29 & 3.93 & 3.89 & 4.15 & 3.68 & 2.88 & 2.77 & 2.86 \\
\hline SER & & 7.37 & 4.59 & 4.49 & 4.90 & 5.34 & 5.59 & 5.62 & 5.65 & 5.19 & 4.75 & 5.29 \\
\hline GLU & & 13.39 & 16.30 & 16.15 & 21.13 & 20.66 & 20.79 & 18.77 & 20.05 & 19.22 & 31.55 & 30.02 \\
\hline PRO & & 4.20 & 5.19 & 4.34 & 6.91 & 10.68 & 11.60 & 5.30 & 6.99 & 5.08 & 12.95 & 14.53 \\
\hline GLY & & 3.70 & 2.36 & 5.35 & 5.73 & 2.06 & 2.12 & 4.43 & 5.53 & 6.58 & 3.99 & 3.86 \\
\hline ALA & & 5.57 & 5.45 & 6.37 & 4.79 & 3.15 & 3.16 & 4.36 & 4.86 & 4.22 & 3.25 & 2.95 \\
\hline VAL & & 5.50 & 5.11 & 4.35 & 4.30 & 4.71 & 4.69 & 4.09 & 4.33 & 3.62 & 4.01 & 3.90 \\
\hline MET & & 2.11 & 1.25 & 1.81 & 1.15 & 1.77 & 1.79 & 0.69 & 1.16 & 0.50 & 0.89 & 0.85 \\
\hline ILE. & & 4.77 & 4.90 & 4.04 & 3.90 & 4.07 & 3.70 & 4.09 & 3.25 & 3.11 & 3.60 & 3.56 \\
\hline LEU & & 9.03 & 12.91 & 8.87 & 8.50 & 9.44 & 9.51 & 8.33 & 8.26 & 7.22 & 7.62 & 7.84 \\
\hline TYR & & 3.73 & 4.14 & 3.92 & 3.26 & 5.68 & 5.40 & 4.10 & 4.28 & 4.41 & 3.20 & 3.87 \\
\hline PHE & & 5.54 & 4.08 & 4.37 & 4.61 & 4.89 & 4.89 & 5.33 & 5.45 & 5.10 & 5.33 & 5.39 \\
\hline HIS & & 2.86 & 2.09 & 4.30 & 3.66 & 2.71 & 2.80 & 3.14 & 2.62 & 2.83 & 2.51 & 2.47 \\
\hline LYS & & 7.15 & 9.21 & 8.95 & 5.89 & 7.72 & 7.55 & 6.45 & 4.33 & 3.88 & 2.54 & 2.07 \\
\hline ARG & & 6.53 & 3.32 & 6.84 & 6.89 & 3.81 & 3.61 & 7.89 & 7.42 & 12.48 & 3.92 & 3.98 \\
\hline TRP & & 0.94 & 1.68 & 1.04 & 1.31 & 1.02 & 1.19 & 0.68 & - & - & - & 0.68 \\
\hline
\end{tabular}

(1) Mean of five separate hydrolyses, except for oatmeal of which 4 determinations were made.

In vitro protein digestion. - Table 3 gives in vitro crude protein and amino acid digestibility after $6 \mathrm{~h}$ of pancreatic digestion. The enzymatic release of nitrogen was linear for $6 \mathrm{~h}$, except for a short lag in the first jour of digestion (data not shown). Generally, proteins of animal origin gave better digestibility values than vegetable proteins, with the exception of peanut meal which was highly digestible, egg proteins which were poorly digested, and ANRC casein that was digested to the same extent as vegetable proteins.

Amino acid release varied mostly with the amino acid but also with the type of protein. Some amino acids were released rapidly from proteins while others were liberated more slowly. Generally, leucine, phenylalanine, tyrosine, lysine 


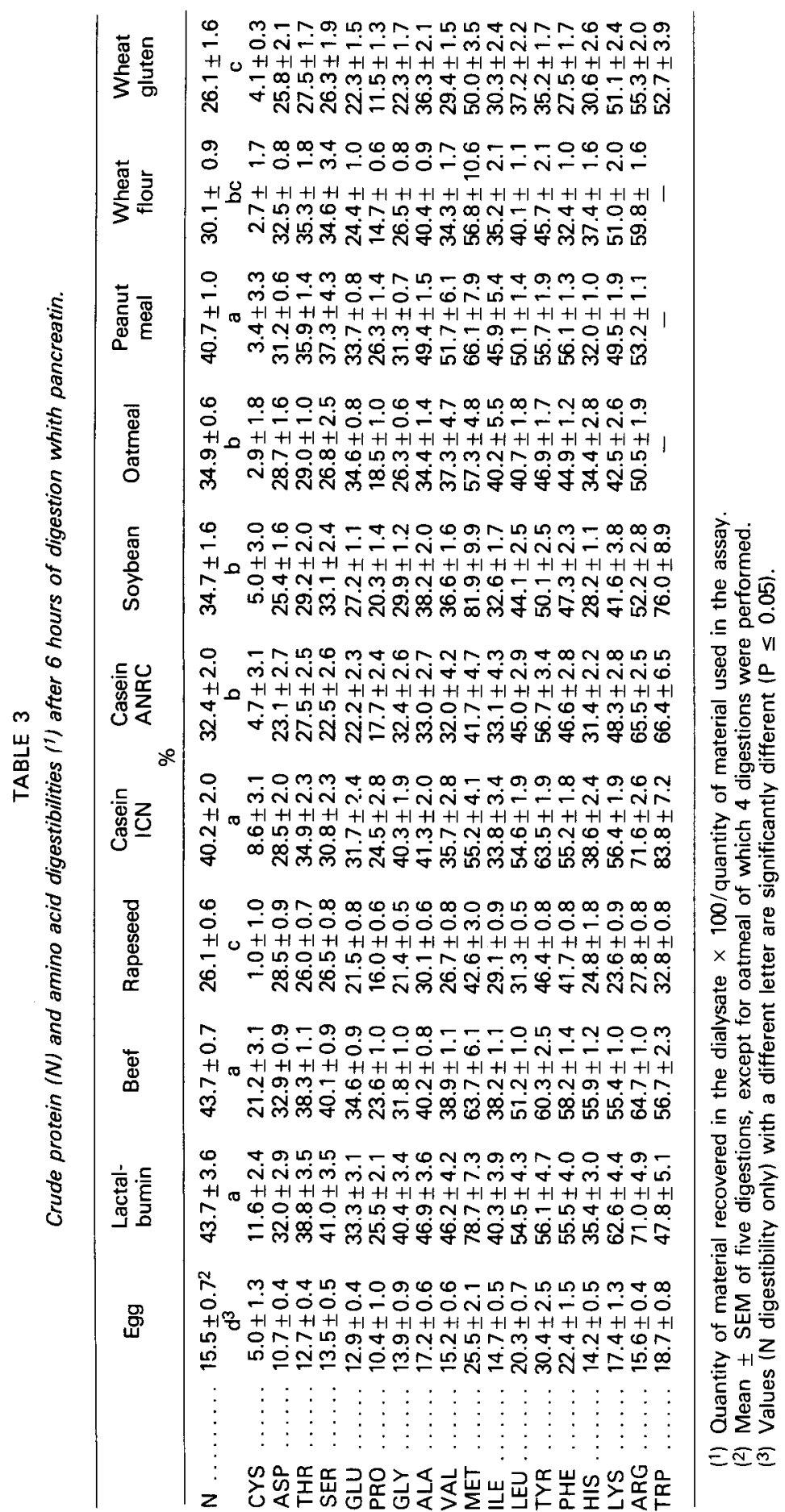


methionine, arginine and tryptophan were released rapidly. Others like threonine, asparctic acid, glutamic acid, and especially cysteine and proline, were liberated slowly. Essential amino acids were generally released more rapidly than nonessential ones.

The nature of the protein also influenced amino acid release. Among the rapidly released amino acids, the release of methionine, lysine and arginine of wheat proteins was very rapid; however, the phenylalanine of these proteins was liberated more slowly than in other proteins. The release of the following amino acids was also notably rapid : methionine of soybean, tyrosine of egg, caseins and rapeseed, arginine of caseins, and tryptophan of all the proteins, except lactalbumin. However, lysine was liberated slowly in rapeseed protein, contrary to other proteins. Finally, the liberation of valine was low in beef and in casein ICN but high in peanut meal. With these differences in amino acid digestibilities, the composition of the digestion products differed markedly from that of the corresponding protein (table 4).

Nutritional evaluation in vivo. - The nutritional evaluation of the proteins, placed in decreasing order according to PER, is given in table 5. Food intake varied with the protein : animal proteins generally gave higher intakes than vegetable proteins, especially wheat proteins. Quality varied markedly with the protein. The PER of the poorest quality protein, wheat gluten, was only $10 \%$ that of egg. Animal proteins had a higher nutritional value than vegetable proteins based on either PER or NPR, except for rapeseed protein whose quality was equivalent to that of casein. Corrected PER values (with ANRC casein fixed at 2.5 : Bieri et al., 1977) are also given. NPR ranked ANRC casein higher than PER. NPR gave a higher nutritional value than PER to the poorest quality froteins, with wheat gluten having as much as $40 \%$ of the nutritional value of egg proteins. The correlation between both tests using individual values was high $(R=0.97, P<0.001)$. Apparent digestibility did not vary much with the protein source, since all values remained between 80 and $90 \%$. In spite of a good correlation with PER $(R=0.34, P<0.01)$ and NPR $(R=0.40, P<0.003)$, digestibility did not account for much of the variation in protein quality. It tended to be related to the purity of the protein source since it decreased with the protein content of the source.

Relationship between in vitro and in vivo data. - Evaluation of in vitro digestibility of nitrogen (6-hour digestibility of table 3) did not correlate with that of in vivo protein quality, $R$ values being $0.05,-0.01$ and -0.13 , respectively, with PER, NPR and apparent digestibility. The use of amino acid composition to predict PER and NPR was tested by stepwise discriminant analysis using either the amino acid composition of the protein $\left(C_{0}\right)$ (see table 2) or that of the in vitro digestion products $\left(C_{d}\right)$ (see table 4). Table 6 gives the regression coefficients of PER and NPR with different amino acid combinations. With both $C_{0}$ and $C_{d}$, PER was calculated with a better degree of confidence when all the amino acids were taken together than when only the essential amino acids were used. The same held true when animal and vegetable proteins were taken separately, except for the PER of animal proteins computed with $C_{0}$. Maximal $R^{2}$ values were obtained 


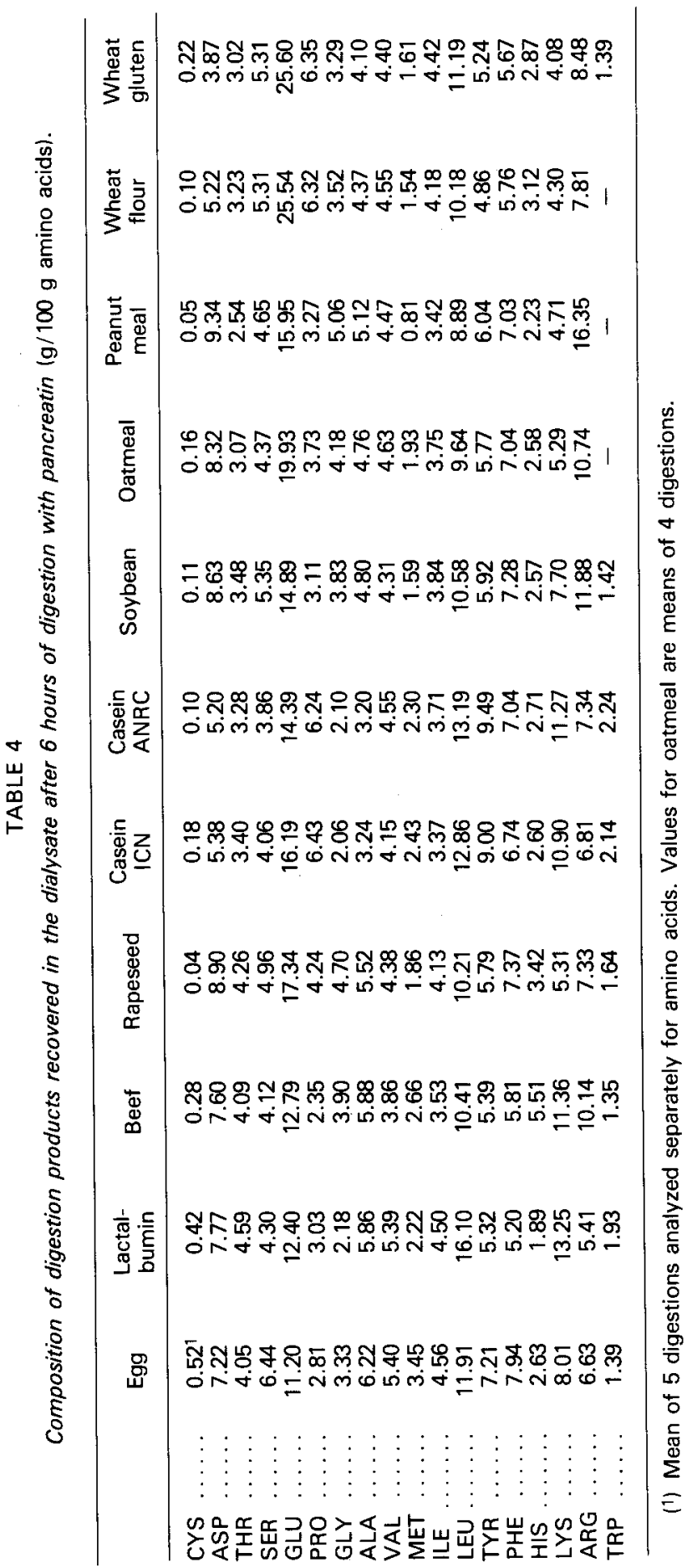


with all the amino acids when the vegetable proteins were taken separately; in this situation, $R^{2}$ with $C_{0}$ and $C_{d}$ was equivalent. However, when all the proteins were included in the test, $C_{d}$ was slightly better than $C_{0}$ and gave a $R^{2}$ value that was almost as high as that obtained when the vegetable proteins were taken separately. NPR-calculated values were obtained with a lower degree of confidence than those of PER, except when the proteins were divided into two groups and the analysis made including essential amino acids only. PER (corrected) was calculated using $\mathrm{C}_{0}$ or $\mathrm{C}_{\mathrm{d}}$ with all the proteins and amino acids by the following equations :

with $\mathrm{C}_{0}, \mathrm{PER}=1.068+0.651 \mathrm{Thr}+0.643 \mathrm{Val}-0.558 \mathrm{lle}$

$$
-0.127 \text { Leu }+0.169 \text { Lys }
$$

with $C_{d}$, PER $=7.365+0.173$ Asp -0.162 Ser -0.073 Glu

$$
-0.185 \text { Pro }-0.212 \text { Gly }-0.190 \text { Leu }+0.166 \text { Tyr }-0.21 \text { Arg }
$$

TABLE 5

Nutritional evaluation of proteins in rats.

\begin{tabular}{lcccccc}
\hline & $\begin{array}{c}\text { Daily food } \\
\text { intake } \\
\text { (g) }\end{array}$ & Absolute & Corrected (1) & NPR & $\begin{array}{c}\text { Apparent } \\
\text { digestibility } \\
(\%)\end{array}$ \\
\hline Egg ........ & $16.4 \pm 0.4 \mathrm{a}^{2.3}$ & $3.54 \pm 0.05 \mathrm{a}$ & 3.07 & $5.07 \pm 0.09 \mathrm{a}$ & $88.5 \pm 0.3 \mathrm{~b}$ \\
Lactalbumin . & $14.1 \pm 0.4 \mathrm{~b}$ & $3.19 \pm 0.04 \mathrm{~b}$ & 2.77 & $4.51 \pm 0.07 \mathrm{~b}$ & $89.3 \pm 0.3 \mathrm{ab}$ \\
Beef ........ $16.0 \pm 0.5 \mathrm{a}$ & $2.97 \pm 0.05 \mathrm{c}$ & 2.58 & $4.30 \pm 0.07 \mathrm{bc}$ & $89.8 \pm 0.2 \mathrm{a}$ \\
Rapeseed ... & $15.8 \pm 0.3 \mathrm{a}$ & $2.92 \pm 0.04 \mathrm{c}$ & 2.53 & $4.17 \pm 0.05 \mathrm{~cd}$ & $87.2 \pm 0.4 \mathrm{c}$ \\
Casein ICN ... & $13.9 \pm 0.5 \mathrm{bc}$ & $2.91 \pm 0.06 \mathrm{c}$ & 2.53 & $3.97 \pm 0.11 \mathrm{~d}$ & $88.7 \pm 0.4 \mathrm{ab}$ \\
Casein ANRC & $12.8 \pm 0.4 \mathrm{c}$ & $2.88 \pm 0.08 \mathrm{c}$ & 2.50 & $4.21 \pm 0.15 \mathrm{~cd}$ & $88.8 \pm 0.6 \mathrm{ab}$ \\
Soybean .... & $13.9 \pm 0.3 \mathrm{bc}$ & $2.31 \pm 0.04 \mathrm{~d}$ & 2.00 & $3.60 \pm 0.07 \mathrm{e}$ & $87.0 \pm 0.3 \mathrm{c}$ \\
Oatmeal ..... & $14.7 \pm 0.3 \mathrm{~b}$ & $2.27 \pm 0.04 \mathrm{~d}$ & 1.97 & $3.49 \pm 0.04 \mathrm{e}$ & $80.7 \pm 0.6 \mathrm{e}$ \\
Peanut meal . & $10.4 \pm 0.4 \mathrm{~d}$ & $1.45 \pm 0.04 \mathrm{e}$ & 1.26 & $2.70 \pm 0.11 \mathrm{f}$ & $80.1 \pm 0.6 \mathrm{e}$ \\
Wheat flour.. & $8.9 \pm 0.2 \mathrm{e}$ & $0.94 \pm 0.06 \mathrm{f}$ & 0.82 & $2.29 \pm 0.08 \mathrm{~g}$ & $84.7 \pm 0.3 \mathrm{~d}$ \\
Wheat gluten & $7.0 \pm 0.3 \mathrm{f}$ & $0.37 \pm 0.08 \mathrm{~g}$ & 0.32 & $2.04 \pm 0.13 \mathrm{~g}$ & $89.7 \pm 0.2 \mathrm{ab}$ \\
\hline
\end{tabular}

(1) Calculated relatively to ANRC casein given a value of 2.50 .

(2) Mean \pm SEM of 10 animals.

(3) Values with a different letter in the same column are significantly different ( $P \leq 0.01$ ).

TABLE 6

Relationship between PER or NPR and amino acid composition of the proteins $\left(C_{0}\right)$

\begin{tabular}{|c|c|c|c|c|c|}
\hline & \multicolumn{2}{|c|}{$\begin{array}{l}\text { All amino } \\
\text { acids }\end{array}$} & & \multicolumn{2}{|c|}{$\begin{array}{l}\text { Essential amino } \\
\text { acids }\end{array}$} \\
\hline & PER & NPR & & PER & NPR \\
\hline \multirow{4}{*}{$\begin{aligned} \mathrm{C}_{0}: & \text { all proteins } \\
& \text { vegetable proteins } \\
& \text { animal proteins }\end{aligned}$} & & & $\mathrm{R}^{2}$ & & \\
\hline & 0.934 & 0.921 & & 0.932 & 0.928 \\
\hline & 0.992 & 0.930 & & 0.971 & 0.978 \\
\hline & 0.844 & 0.718 & & 0.912 & 0.912 \\
\hline $\mathrm{C}_{\mathrm{d}}:$ all proteins & 0.981 & 0.941 & & 0.912 & 0.897 \\
\hline vegetable proteins & 0.990 & 0.941 & & 0.974 & 0.985 \\
\hline animal proteins & 0.928 & 0.880 & & 0.760 & 0.877 \\
\hline
\end{tabular}
or their in vitro digestion products $\left(C_{d}\right)$. 
These amino acids were those retained by the computer as being the discriminant ones by a stepwise procedure. Table 7 gives the PER-calculated values with $\mathrm{C}_{0}$ and $\mathrm{C}_{\mathrm{d}}$ and the difference from the corrected PER. Positive and negative differences were observed, depending on the protein source. Absolute differences of 0.3 or more were obtained for beef, rapeseed protein and wheat gluten when $\mathrm{C}_{0}$ was used. A better calculation of PER was achieved with $\mathrm{C}_{d}$ since the differences did not exceed 0.09 and were generally lower than 0.05 ; the differences between measured- and calculated-PER values for the three proteins mentioned above, i.e. beef, rapeseed and wheat gluten, were then only $0.01,0$ and 0.07 , respectively.

TABLE 7

PER-calculated values and the differences with the corrected PER using regression equations from either the amino acid composition of the protein $\left(C_{0}\right)$ or that of the in vitro digestion products $\left(C_{d}\right)$.

\begin{tabular}{|c|c|c|c|c|}
\hline & \multicolumn{2}{|c|}{ With $\mathrm{C}_{0}$} & \multicolumn{2}{|c|}{ With $C_{d}$} \\
\hline & $\begin{array}{l}\text { Calculated } \\
\text { values }\end{array}$ & $\begin{array}{l}\text { Difference with } \\
\text { corrected PER (1) }\end{array}$ & $\begin{array}{l}\text { Calculated } \\
\text { values }\end{array}$ & $\begin{array}{l}\text { Difference with } \\
\text { corrected PER (1) }\end{array}$ \\
\hline Egg $\ldots \ldots$ & 3.06 & -0.01 & 3.06 & -0.01 \\
\hline Lactalbumin & 2.77 & 0.00 & 2.77 & -0.00 \\
\hline Beef ...... & 2.90 & 0.32 & 2.59 & 0.01 \\
\hline Rapeseed. & 2.23 & -0.30 & 2.53 & 0.00 \\
\hline Casein ICN .. & 2.35 & -0.18 & 2.44 & -0.09 \\
\hline Casein ANRC & 2.48 & -0.02 & 2.51 & 0.01 \\
\hline Soybean ..... & 2.01 & 0.01 & 1.98 & -0.02 \\
\hline Oatmeal ... & 1.98 & 0.01 & 1.93 & -0.04 \\
\hline Peanut meal & 1.14 & -0.12 & 1.25 & -0.01 \\
\hline Wheat flour. & 0.77 & -0.05 & 0.85 & 0.03 \\
\hline Wheat gluten & 0.67 & 0.35 & 0.39 & 0.07 \\
\hline
\end{tabular}

(1) Corrected PER values given in Table 5 .

\section{Discussion.}

Test proteins were enzymatically digested in vitro in order to establish a relationship between the nature of in vitro digestion products and protein quality evaluated in vivo. The animal proteins generally showed better digestibilities than the vegetable proteins both in vitro and in vivo. One explanation is that the former contain more essential amino acids that are generally the specific targets of digestive enzymes (Fruton, 1971 ; Gray and Cooper, 1971). However, vegetable proteins contain more arginine, which could have obscured the above difference in digestibility between animal and vegetable proteins. For instance, peanut meal that had by far the highest arginine content was the most highly digested vegetable protein in vitro.

The non-protein components of a foodstuff are known to interfere with protein digestion (Silano, 1976). Apparent digestibility is generally inferior in proteins sources of low protein content such as most of the vegetable proteins tested in 
this work. Contrarily, in vitro digestion was independent of the purity of the protein source, indicating that this type of digestion is more related to the protein itself than to its non-protein components.

Unlike in vivo digestibility, in vitro digestibility varied with the protein. The wider range of digestibility values obtained in vitro also resulted from the fact that digestion was intentionally stopped before it was completed. With a longer digestion time, it is conceivable that the difference in protein digestibility would level out, as has already been shown for amino acid release (Vachon et al., 1983). The measurement of these parameters after a shorter digestion time provided a better discrimination of the proteins, even if it probably increased the variability of the in vitro measurements.

Raw egg protein was not well digested in vitro, probably due to the active enzyme inhibitors present in eggs (Liu et al., 1971) and normally inactivated by heat (Silano, 1976). Our egg preparation was not heat-treated to prevent modification of the structure of the protein source. In vivo, the organism adapts to dietary enzyme inhibitors by increasing enzyme activities (Green and Nasset, 1983) so that digestion may be almost complete. However, in spite of the low extent of digestion, the composition of the digestion products of this protein still reflected its nutritional value.

It should be emphasized that apparent digestibility did not fully explain protein quality since the values ranged between 80 and $90 \%$. This would indicate that amino acid availability, instead of only nitrogen digestibility, must be considered when measuring protein quality. Amino acids released in vitro reflected digestive enzyme specificity (mostly pancreatic) and also the nature of the protein, as already observed by Vachon et al. (1982, 1983). Consequently, the amino acid composition of the digestion products was markedly different from that of the corresponding protein. The present finding illustrates the impact of digestion on the biological effects of proteins since $C_{d}$ gave a better prediction of PER and NPR than $C_{0}$. However, the non-protein components varied with the protein source. Since the values of the two growth tests might vary with this parameter, it is possible that their relationship with $C_{0}$ or $C_{d}$ was also affected.

A high digestibility value in vitro was generally found for lysine, especially in cereals, while the availability of this amino acid is low in vivo (Darcy et al., 1982; Sauer et al., 1977). We believe that the in vitro data reflect a real biological process occurring at the very onset of digestion. This phenomenon could be compensated by intestinal absorption : the in vitro method thus provides a useful tool for investigating phenomena that are not detectable in vivo.

The increase of $\mathrm{R}^{2}$ from 0.934 to 0.981 was relatively slight. However, not only the differences between measured PER and PER-calculated values were lower with $C_{d}$ than with $C_{0}$, but almost all the test proteins were improved (table 7). The correction was marked with vegetable proteins such as gluten or rapeseed that are often underevaluated by PER (Evans and Witty, 1978). When animal and vegetable proteins were separated into two sub-groups, the predictability of animal protein PER and NPR deteriorated. This may be because the range of nutritional values in this group was much narrower (corrected PER values from 2.50 to 3.07 ) than that of vegetable proteins (PER of 0.32 to 2.53 ). 
Prediction precision was also reduced when the non-essential amino acids were excluded from the test. In fact, the PER was predicted better by an equation using a high positive constant that was reduced according to the content of some, mostly non-essential, amino acids. This finding indicated the importance of non-essential amino acids to protein quality, as indicated by other investigators (Sheffner et al., 1980).

The relationship between in vitro and in vivo data was established using the most global in vivo approach, i.e. by measuring the final effect of amino acids on growth. The relationship was generally better with in vitro digestion products than with protein amino acid composition. Also, the correlation with the protein quality of some vegetable proteins was noticeably improved. Contrary to other procedures (Satterlee et al., 1982), this can be interpreted as a correction for amino acid digestibility that the proposed in vitro method provides. This method can be applied to studies of variables likely to affect amino acid availability, such as alkaline or heat treatment, protein extraction or purification or anti-nutritional factors. However, the appropriateness of the method as a measurement of amino acid availability must be further evaluated by comparing in vitro digestion products with ileal digestibility of amino acids, their appearance in portal blood, and their utilization by the liver and peripheral tissues. These studies are currently in progress in rats and pigs.

Reçu en août 1986. Accepté en février 1987.

Acknowledgments. - This work was supported by grants No. G 0619 from Natural Sciences and Engineering Research Council of Canada and No. EQ-1188 from the "Ministère de I'Education du Québec " and the J. Rhéaume Foundation.

Résumé. Corrélation entre la digestion in vitro des protéines et leur évaluation nutritionnelle in vivo.

La relation entre la nature des produits de digestion in vitro et l'évaluation nutritionnelle des protéines chez le rat a été examinée. Onze sources de protéines animales ou végétales, plus ou moins pures, ont été digérées avec de la pepsine, puis de la pancréatine dans un sac à dialyse d'exclusion moléculaire de 1000 . Généralement les protéines animales sont mieux digérées in vitro que les protéines végétales. La libération de chacun des acides aminés dépend de la spécificité des enzymes digestives et du type de protéine. Les acides aminés essentiels sont en général libérés plus rapidement que les acides aminés non essentiels. De ce fait, la composition des produits de digestion diffère fortement de celle de la protéine au départ. Dans nos conditions expérimentales, la digestibilité in vitro varie beaucoup plus d'une protéine à l'autre que la digestibilité mesurée chez le rat, de sorte que les deux mesures ne correspondent pas. Par contre, une analyse par régression linéaire multiple montre que le coefficient d'efficacité protéique (CEP) correspond un peu plus au profil en acides aminés des produits de digestion in vitro qu'à celui de la protéine, avec des $R^{2}$ respectivement de 0,981 et 0,934 . L'analyse avec le coefficient protéique net donne une correspondance un peu plus faible avec des $R^{2}$ de 0,941 et 0,921 . En utilisant les équations de régression en vue de prédire le CEP, l'amélioration qui est abservée pour l'ensemble des protéines lorsque sont utilisés les produits de digestion plutôt que la composition de la protéine, est plus marquée pour certaines d'entre elles soit le bœuf, le colza et le gluten de blé. Ces résultats montrent une certaine incidence de la disponibilité des acides aminés dans la qualité nutritionnelle des protéines. 


\section{References}

BIERI J. G., STOEWSAND G. S., BRIGGS G. M., PHILLIPS R. W., WOODARD J. C., KNAPKA J. J., 1977. Report of the American Institute of Nutrition Ad Hoc Committee on standards for nutritional studies. J. Nutr., 107, 1340-1348.

BLOOMGARDEN Z. T., LILJENQUIST J., LACY W., RAVIN D., 1981. Amino acid disposition by liver and gastro-intestinal tract after protein and glucose ingestion. Am. J. Physiol., 241, E90E99.

BUCHANAN R. A., 1969. In vivo and in vitro methods of measuring nutritive value of leaf-protein preparation. Br. J. Nutr., 23, 533-545.

CHRISTIAN K. R., COUP M. R., 1954. Measurement of feed intake by grazing cattle and sheep. VI. The determination of chromic oxyde in faeces. N. Z. J. Sci. Tech., 36, 328-330.

DARCY B., LAPLACE J. P., DUÉE P. H., 1982. Digestion des protéines dans l'intestin grêle chez le porc. I. Digestibilité des acides aminés selon la source de protéines d'un régime à base d'amidon de maïs purifié. Ann. Zootech., 31, 279-300.

DUNCAN D. B., 1955. Multiple range and multiple $\mathrm{F}$ tests. Biometric, 11, 1-42.

EVANS E., WITTY R., 1978. An assessment of method used to determine protein quality. WId Rev. Nutr. Diet., 32, 1-26.

FORSUM E., 1975. Effect of dietary lactose on nitrogen utilization of a whey protein concentrate and its corresponding amino acid mixture. Nutr. Rep. Int., 11, 419-428.

FRUTON J. S., 1971. Pepsin. In : Boyer, P. D., The enzymes. Vol. 3, Hydrolysis : peptide bonds. Chap. 4, Acad. Press, New York.

GAUTHIER S. F., VACHON C., JONES J. D., SAVOIE L., 1982. Assessment of protein digestibility by in vitro enzymatic hydrolysis with simultaneous dialysis. J. Nutr., 112, 1718-1725.

GAUTHIER S. F., VACHON C., SAVOIE L., 1986. Enzymatic conditions of an in vitro method to study protein digestion. J. Food Sci., 51, 960-964.

GRAY G. M., COOPER H. L., 1971. Protein digestion and absorption. Gastroenterology, 61, 535-544.

GREEN G. M., NASSET E. S., 1983. Role of dietary protein in rat pancreatic enzyme secretory response to a meal. J. Nutr., 113, 2245-2252.

JEWELL D. K., KENDRICK J. G., SATTERLEE L. D., 1980. The DC-PER assay: A method for predicting protein quality solely from amino acid compositional data. Nutr. Rep. Int., 21, 25-38.

LIU W. H., MEANS G. E., FEENEY R. E., 1971. The inhibitory properties of avian ovo-inhibitors against protelolytic enzymes. Biochem. Biophys. Acta, 229, 176-185.

MAURON J., MOTTU F., BUJARD E., EGLI R. H., 1955. The availability of lysine, methionine and trytophan in condensed milk and milk powder. In vitro digestion studies. Arch. Biochem. Biophys., 59, 433-451.

PELLETT P. L., YOUNG V. R., 1980. Some rat and human assay procedures, 103-117. PELLET P. L., YOUNG V. R. In Nutritional evaluation of protein foods. United Nations Univ., Tokyo.

SARWAR G., CHRISTENSEN D. A., FINLAYSON A. J., FRIEDMAN M., HACKLER L. R., MACKENZIE S. L., PELLETT P. L., TKACHUK R., 1983. Inter- and intra-laboratory variation in amino acid analysis of food proteins. J. Food Sci., 48, 526-531.

SAS Institute., 1979. Statistical Analysis System user's guide. Cary, N. C.

SATTERLEE L. D., KENDRICK J. G., MARSHALL H. F., JEWELL D. K., ALI R. A., HECKMAN M. M., STEINKE H. F., LARSON P., PHILLIPS R., SARWAR G., SLUMP P., 1982. In vitro assay for predicting protein efficiency ratio as measured by rat bioassay : collaborative study. J. Assoc. Off. Anal. Chem., 65, 798-809.

SAVOIE L., GAUTHIER S. F., 1986. Dialysis cell for in vitro measurement of protein digestibility. J. Food Sci, 51, 494-498.

SAUER C., STOTHERS S. C., PHILLIPS G. D., 1977. Apparent availabilities of amino acids in corn, wheat and barley for growing pigs. Can. J. anim. Sci., 57, 585-597.

SHEFFNER A. L., ECKFELDT G. A., SPECTOR H., 1956. The pepsin digest residue (PDR) amino acid index of net protein utilization. J. Nutr., 60, 105-120.

SILANO V., 1976. Factors affecting digestibility and availability of proteins in cerals. In Nutritional evaluation of cereal mutants. Int. At. Energy Agency (IAEA), Vienna, 13-46. 
SIMPSON R. J., NEUBERGER M. R., LIEU T. Y., 1976. Complete amino acid analysis of proteins from a single hydrolysate. J. biol. Chem., 251, 1936-1940.

STAHMANN M. A., WOLDEGIORGIS G., 1975. Enzymatic methods for protein quality determination, 231-234. In FRIEDMAN M., Protein nutritional quality of foods and feeds, part 1, Marcel Dekker, New York.

VACHON C., GAUTHIER S. F., JONES J. D., SAVOIE L., 1982. Enzymatic digestion method with dialysis to assess protein damage ; application to alkali-treated proteins containing lysinoalanine. Nutr. Res. 2, 675-688.

VACHON C., GAUTHIER S. F., JONES J. D., SAVOIE L., 1983. In vitro enzymatic release of amino acids from alkali-treated proteins containing lysinoalanine. Nutr. Rep. Int., 27, 1303-1313. 